\title{
Comment on "An enigmatic, possibly chemosymbiotic, hexactinellid sponge from the early Cambrian of South China" by Joseph P. Botting, Lucy A. Muir, Xiang-Feng Li, and Jin-Pai Lin
}

\author{
ANDREY YU. ZHURAVLEV, JOSÉ ANTONIO GÁMEZ VINTANED, \\ and KONSTANTIN R. TABACHNICK
}

Botting, Muir, Li, and Lin (2013) describe an early Cambrian, possibly chemosymbiotic, hexactinellid Decumbispongia yuani on six specimens (five are pictured) from the Hetang Formation of Anhui and the Niutitang Formation of Guizhou, South China. The fossils are three-dimensionally preserved, semi-toroid, rounded in cross-section (variously compressed), slightly tapering towards one or both ends, and weakly ribbed, bearing irregularly clustered, poorly preserved, orthogonal to diagonal hexactine-based spicule impressions on their surface.

The authors correctly reject a possibility that this fossil can be remains of an agglutinating organism bearing detrital spicules due to its more or less regular spicule arrangement. At the same time, they emphasise that Decumbispongia differs from intact sponges (common in both formations), by its three-dimensional rather than strongly flattened preservation and by the fact that spicules are usually pyritised or preserved as external moulds with partial replacement by aluminosilicates or silica (Xiao et al. 2005).

Although an atrial cavity is absent in bilaterally-symmetrical hexactinellids with loose spicule arrangement such as Poliopogon, Sericolophus, Platylistrum, and some Pheronema species of the Pheronematidae family, their inverted atrial surface differs from the surface of Decumbispongia. All other Recent genera lacking an atrial cavity and an atrial surface are rigid sponges alike hornyform Sclerothamnus and Sclerothamnopsis (Tretodictyidae) with a distinctive channelisation pattern of schizorhyses. Besides, the fossil lacks any traces of the aquiferous system, its lying posture and shape are incompatible with a filter-feeding poriferan life style, and the spicules are visible clearly as voids on some areas of one specimen (paratype NIGP154190; Botting et al. 2013: fig. 1B). The authors interpret these drastic differences from fossil and Recent sponges together with strict control of body orientation through the unique morphology and restriction to largely anoxic facies in favour of a chemosymbiotic nature.

However, there are no hexactinellids in the Recent world having a chemosymbiotic nutrition, perhaps, due to their peculiar syncytial soft tissue organisation. A common presence of abundant and diverse bacterial symbionts taking part in sponge feeding, thus, allowing some researchers even to coin the term "bacterio-sponges" hardly is an argument in favour of the chemosymbiotic nature of Decumbispongia. Human beings can be equally called "bacterio-humans" due to their rich and extremely diverse bacterial inner biota responsible for various functions (McFall-Ngai et al. 2013). To prove a chemosymbiont nature of a given fossil, convincing stable isotope data, at least carbon and sulphur ones, are needed. Besides, if specimens' massive pyritisation was produced by sulphate-reducing bacteria inside live tissues, the process would have eventually threatened the host and bacteria would not be real "endosymbionts". Pyritisation may have simply been promoted by abundance of organic matter in fossils.

There is another kind of fossils which the authors do not take into consideration: the bioturbation and biodeposition structures, or bromalites including coprolites and cololites, all of which are common Cambrian fossils. Bioturbation structures are mostly three-dimensional and some of them are impregnated with hexactine spicules in such a manner that they even are described as hexactinellids-Multivasculatus from the middle Cambrian of North America (Howell and Van Houten 1940) and Aulophycus from the lower Cambrian of the Siberian Platform (Astashkin 1985). Both fossils possess a tubular form, up to $700 \mathrm{~mm}$ in depth and $30 \mathrm{~mm}$ in diameter, and are vertically oriented if preserved in situ, while their spicules are restricted to the wall which differs from the sediment by its mineralogy (dolomite versus calcite in carbonate facies); the central cavity in turn is filled with synsedimentary marine and burial cements. Their general habit and restriction to neritic facies as well as the wall composition commonly containing pellets, echinoderm ossicles, and other detritus reveal affinities to Ophiomorpha and similar forms.

Non-peletoidal, invertebrate coprolites (fossil faeces) range from straight to strongly curved and semi-toroid; they are relatively short except for quickly-ejected forms which are winding and smooth, one of the ends can be markedly more acute than the other, and strong constrictions appear half-way through (both features are sphincter-made; Botting et al. 2013: fig. 1C, E); preservation can be either two- or three-dimensional with a flattened ventral side (op. cit.: fig. 1A). Cambrian coprolites being compared in coherent shape and size with Decumbispongia contain diverse skeletal elements, mostly hyolith 
conchs, brachiopod shells, and bivalved arthropod carapaces which are well-preserved, display a marked contrast with surrounding sediments, and, in some cases, are sorted and aligned into oriented rows (Conway Morris and Robison 1986; Vannier and Chen 2005). Such an aggregate composed of siliceous Volborthella conchs has been even described from the lower Cambrian of the Great Basin as a molluscan radula Campitius (Firby and Durham 1974). A near-isometric "growth" does not preclude such an interpretation, as coprolites being formed at different growth stages of the same organism would display a near-isometric plot (Vannier and Chen 2005: fig. 3). However, no spicules are distinguished in such fossils until now.

Invertebrate cololites (fossilised digestive tracts with their contents) can be three-dimensionally preserved, cylindrical to irregular, elipsoidal or (frequently) winding (in this case, with strong constrictions), slightly tapering towards one or both ends; they can also be sponge spicule-impregnated (Ivantsov et al. 2005a; Vannier 2012; Zhu et al. 2013). Usually, the guts are intact to body fossils themselves but due to a more resistant composition can be still preserved even if the embracing skeleton is dissolved. In the cited cases, the cololites belong to ecdysozoans, either arthropods or cephalorhynch worms. The cololite of the lower Cambrian trilobite Bergeroniellus spinosus from the Siberian Platform reported by Ivantsov et al. (2005a: 75, pl. 26: 4; 2005b) is of special interest because the fossil is restricted to largely anoxic facies and contains well-preserved hexactine-based spicules being arranged in the same manner as in Decumbispongia.

In conclusion, these fossils are preferably interpretated as ecdysozoan bromalites, including coprolites (Botting et al. 2013: fig. 1A, C, E) and probably cololites (specimens in fig. $1 \mathrm{~B}$ and $1 \mathrm{D}$ are doubtful). Three-dimensional preservation of the fossils was probably enhanced by bacterial early mineralisation (prefossilisation sensu Seilacher 2002).

\section{References}

Astashkin, V.A. [Astaškin, V.A.] 1985. Problematic rock-forming organisms in the lower Cambrian strata of the Siberian Platform [in Rus- sian]. In: B.S. Sokolov and I.T. Zhuravleva [I.T. Žuravleva] (eds.), Problematiki pozdnego dokembriâ i paleozoâ. Institut Geologii i Geofiziki, Sibirskoe Otdelenie, Akademiâ Nauk SSSR, Trudy 632: 144-149.

Botting, J.P., Muir, L.A., Li, X.-F., and Lin, J.-P. 2013. An enigmatic, possibly chemosymbiotic, hexactinellid sponge from the early Cambrian of South China. Acta Palaeontologica Polonica 58: 641-649.

Conway Morris, S. and Robison, R.A. 1986. Middle Cambrian priapulids and other soft-bodied fossils from Utah and Spain. University of Kansas Paleontological Contributions 117 (for 1985): 1-22.

Firby, J.B. and Durham, J.W. 1974. Molluscan radula from earliest Cambrian. Journal of Paleontology 48: 1109-1119.

Howell, B.F. and Van Houten, F.B. 1940. A new sponge from the Cambrian of Wyoming. Bulletin of the Wagner Free Institute of Science 15: 1-8.

Ivantsov, A.Yu. [Ivancov, A.Û.], Zhuravlev, A.Yu. [Žuravlev, A.Û.], Krasilov, V.A., Leguta, A.V., Mel'nikova, L.M., Urbanek, A., Ushatinskaya, G.T. [Ushatinskaâ, G.T.], and Malakhovskaya, Ya.E. [Malahovskaâ, Â.E.] 2005a. Unique Sinsk localities of early Cambrian organisms (Siberian Platform) [in Russian]. Paleontologičeskij Institut, Akademiâ Nauk SSSR, Trudy 284: 1-143.

Ivantsov, A.Yu., Zhuravlev, A.Yu., Leguta, A.V., Krassilov, V.A., Melnikova, L.M., and Ushatinskaya, G.T. 2005b. Palaeoecology of the Early Cambrian Sinsk biota from the Siberian Platform. Palaeogeography Palaeoclimatology Palaeoecology 220: 69-88.

McFall-Ngai, M., Hadfield, M.G., Bosch, T.C.G., and 23 others. 2013. Animals in a bacterial world, a new imperative for the life sciences. Proceedings of the National Academy of Sciences of the United States of America 110: 3229-3236.

Seilacher, A. 2002. Non olet: the strange taphonomy of coprolites and cololites. In: M. de Renzi, M.V. Pardo Alonso, M. Belinchón, E. Peñalver, P. Montoya, and A. Márquez-Aliaga (eds.), Current Topics on Taphonomy and Fossilization. Col-lecció Encontres, 5, 233-240. Ajuntament de Valencia, Valencia.

Vannier, J. 2012. Gut content as direct indicators for trophic relationships in the Cambrian marine ecosystem. PLoS ONE 7 (12): e52200.

Vannier, J. and Chen, J. 2005. Early Cambrian food chain: New evidence from fossil aggregates in the Maotiansahan Shale biota, SW China. Palaios 20: 3-26.

Xiao, S., Hu, J., Yuan, X., Parsley, R.L., and Cao, R. 2005. Articulated sponges from the Early Cambrian Hetang Formation in southern Anhui, South China: their age and implications for early evolution of sponges. Palaeogeography, Palaeoclimatology Palaeoecology 220: 89-117.

Zhu, X., Lerosey-Aubril, R., and Esteve, J. 2013. Gut content fossilization and evidence for detritus feeding habits in an enrolled trilobite from the Cambrian of China. Lethaia 47: 66-76.

Andrey Yu.Zhuravlev [ayzhur@mail.ru], Geological Institute, Russian Academy of Sciences, Pyzhevskiy pereulok 7, Moscow, 119017, Russia;

José Antonio Gámez Vintaned [gamez@unizares], Área de Paleontología-IUCA, Universidad de Zaragoza, Pedro Cerbuna 12, E-50009 Zaragoza, Spain;

Konstantin R. Tabachnick [tabachnick@mail.ru], P.P. Shirshov Institute of Oceanology, Russian Academy of Sciences, Nakhimovskiy prospekt 36, Moscow, 117997, Russia.

Received 22 January 2014, accepted 18 March 2014, available online 21 March 2014.

Copyright $(2014$ A.Yu. Zhuravlev et al. This is an open-access article distributed under the terms of the Creative Commons Attribution License, which permits unrestricted use, distribution, and reproduction in any medium, provided the original author and source are credited. 